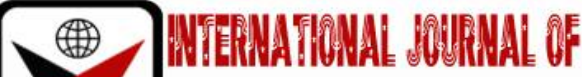

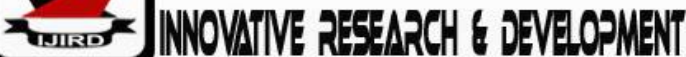

ISSN 2278 - 0211 (Online)

\section{Expressions of Political and Patriotism/National Pride Values as Determinants of Sport Participation among Adolescents in Rivers State, Nigeria}

Dr. Ezomoh Olusoga Olumide,
Senior Lecturer, Department of Human Kinetics and Health Education,
University of Portharcourt, Nigeria
Alaubi Stanley
Lecturer, Department of Human Kinetics and Health Education,
University of Portharcourt, Nigeria

\begin{abstract}
:
The study investigated the expressions of political and patriotism/national pride values as determinants of sport participation among adolescents in Rivers State. Consequently, the descriptive survey research design was adopted for the study. The participants consisted of nine hundred and sixty (960) secondary school adolescents, drawn from all the three Senatorial Districts of Rivers State as follows; Rivers West: (320); Rivers East: (320) and Rivers South East: (320). The participants were drawn using the convenient/accidental sampling technique. The research instrument for this study was the structured questionnaire, with a correlation co-efficient value of 0.91. The inferential statistics of linear regression was used to test the hypotheses at 0.05 Alpha levels. The findings of the study revealed that political and patriotism/national pride values were determinants of sport participation among adolescents in Rivers State. The study therefore, recommended that adolescents should be more encouraged to participate in sports. Enlightenment programmes on the values inherent from sports participation should be organized for the adolescents periodically. Through this, many adolescents who do not know the values of sports participation will be informed and consequently get involved in sports participation and adolescents should be encouraged to participate in sports by providing assistance in form of money, equipment among others to them, as that will sustain their interest and facilitate their participation in sports.
\end{abstract}

Keywords: Political, patriotism/national pride values, determinants, sport participation

\section{Introduction}

Sport is a universal phenomenon that encompasses all forms of physical activities in various dimensions primarily designed for the growth of the individuals physically, mentally and socially. The history of sports dates back to the 'Stone age' when man used physical activities as a man's means of hunting and protecting himself from wild animals (Van Dalen \& Bennet,2001). They stated further that among the early people, physical activities were regarded as only useful for searching for food and survival requirements acquired through the development of strength, endurance, agility and skills needed to withstand the rigours of outdoor (Sporting) activities. Sport has played a part in the lives of people all over the world and today sport is seen not just as mere physical activities, but a means of livelihood and a political weapon as well as unifying factors.

Generally, sport is not a concept which is precisely defined, as the concept of sports and games are mostly used interchangeably. Sport can be regarded as an institution and social system with far reaching effects for human beings in many social contexts such as social, psychological, political, economic and to mention just a few. According to Bucher (1989), sport again is an institutionalized competitive activity which involves strenuous exertion or put differently, the use of relatively complex physical skills by the individual whose participation may be motivated. At is thus regarded as a social institution that faithfully teaches and reinforces societal values, thereby contributing to socializing athletes into major cultural, social and behavioural patterns of the society.

According to Grimes (2009), the idea of organized sports came into existence with the advent of Greek civilization. Since then organized sports were seen by some as personal contests in which individuals compete against individuals, while others view them as political contests in which the honour of one nation is pitched against that of another. He stated further that, the nationalistic attitude has long been with sports, since the ancient Olympics, even when Baron Pierre de Couberton reviewed modern Olympics, he did it with the aim of re-invigorating the youth of France. Hitler saw the Berlin games as a test of the power of the German Youth and Nazism. United States and Soviet Union maintain that these games 
serve as a test of their respective political systems. Developing countries sought nationalistic benefits from participating in international contests.

According to Awosika (2000), sport has been found to be an instrument of patriotism. Individuals, especially in a multi-national country like Nigeria could be easily integrated using sport as cohesive agent. This way, the individuals in a group can identify with their countries and government policies. It has been asserted by different scholars (Van Dalen \& Bennett, 2001; Voltmer \& Esslinger 2002; \& Andah2006) that sports today have assumed a global dimension with well coordinated programmes. It has moved from the level of enjoyment, recreation and entertainment to the level of being an instrument of nationalism and politics. It is a generic term which comprises of all arms of activities which requires competition between two or more people.

Igbanugo (1996) stated that with perhaps the exception of politics, sports is the most competitive field of all human endeavours. Sports happily have come to be recognized as one of the most active ways of building up and mounting of character and personality of individuals. It also helps in promoting unity and solidarity among and within a community or society. Therefore, all concerned in character, moral and spiritual training of individuals must be involved in sports. In virtually all areas of human endeavour, patriotism and national pride are key factors in the attainment or actualization of set goals. One major area of human activity where patriotism and national pride had and still propel man to excellence is sports. Given the increasingly significant role of sports in modern society, sportsmen and women are more than ever before, seen as a mirror of their respective societies and establishments.

Sport in its well developed form is an integral part of the total make up of the society. Sports is recognized by nations and governments of nations as a tool for national mobilization, cultural orientation, national integration and unity, youth development and socialization, national pride and prestige acculturational weapon, national expansion and imperialism (Ikhioya, 1996). Ebhojiaye (1992) asserted that when a country defeats another in a sporting engagement, it connotes a healthier nation, more fit and even more powerful than the other. By the same extension, the country's image is further boosted and reverend among others. Most small nations of the world have today been able to make their names known globally through sports,such nations as Chile, Sweden, Finland, Spain just to mention a few.

Sport is a pervasive human activity such that ignoring it is to overlook one of the most important aspects of contemporary Nigerian society. It is a social phenomenon which extends into education, politics, economy, art the mass media and even international diplomatic relations. Nowadays, involvement in sport, either directly as a participant or indirectly as a spectator, is almost considered a public duty by many people all over the world.

Today, most countries of the world use sport as an instrument of international policy. Indeed, as far back as the early 1960s, sport was used as a visible example of the success of ideological political system. As stated by Morton (2013), 'the soviets have made serious business out of sport competition. They have forged a direct propaganda link between sport triumph on one hand and the validity of a social system on the other. Adesanya (2002), opined that today, sport in the contemporary society has become a persuasive social phenomenon with ramifications for education, politics, economics, arts, defence, happiness and development.

Sports have assumed a fundamental dimension in the global politics of the twentieth century, and even as a potential tool for nation building as we are gradually moving in the new millennium. With the activities of the united Nations Organization (U.N.O), together with its various agencies, and other fostering agencies, emphasis has now been shifted from wars which dominated the pre-20 th century era to sports. Sports now serve as the measure of strength among nations of the world. Sport has assumed a global dimension with well-defined and co-ordinated programmes. Sports have moved from just level of enjoyment, recreation and entertainment alone to being an instrument of nationalism and politics (Van Dallen\& Bennett, 2001; Voltmer \& Esslinger, 2002\& Andah 2006).

Sports in Nigeria is more than running, jumping, throwing or going for external objects for scoring points or goals. The sporting culture has been very revealing as it is bounded up with nation's history, traditions, geography, trade, politics, religions, natural wealth and even nations' health. It has been discovered that a nation's devotion to sports is one of the most powerful denominations to the national political stability (Awosika,2005).Sports have played a part in the lives of many people all over the world and today sport is seen not just as mere physical activities, but as a means of livelihood and a political weapon as well as unifying factors.

Rivers State was created on May 27, 1969 and constitutes one of the earliest states which came into being upon the dissolution of the old regional structure. Rivers State is one of the 36 states in Nigeria; its capital is Port Harcourt. It is bounded on the south by the Atlantic Ocean, to the North by the Anambra, Imo and Abia States, to the East by Akwa-Ibom State and to the West, by the Bayelsa and Delta States (NigeriaGallery, 2015)

Rivers State is the nerve centre of the famous Nigerian oil industries and over ninety industrial concerns, including the Shell Petroleum Development Company of (Nigeria) Limited, Agip, Texaco, Elf, NPRC, West African Glass industry, Alcan Aluminum, Metaloplastic, NAFCON, to mention a few. (NigeriaGallery, 2015). By the 2006 census, Rivers State is inhabited by 5, 198, 718 people (Nigerian Population Commission, 2006).

Presently, there are 23 Local Government Areas; 12 are urban while 11 are sub-urban. Rivers State is in the SouthSouth geo-political zone of Nigeria, which is among the oil rich states in the Niger Delta region of Nigeria. It is highly industrialized. It is grouped into upland and River-rine areas.

\section{Methodology}

The participants for the study consisted of nine hundred and sixty (960) secondary school adolescents, drawn from all the three Senatorial Districts of Rivers State as follows;Rivers West: (320); Rivers East: (320) and Rivers South East: (320). The participants were drawn using the convenient/accidental sampling technique. The research instrument 
for this study was the structured questionnaire, with a correlation co-efficient value of 0.91 . The inferential statistics of linear regression was used to test the hypotheses at 0.05 Alpha levels.

\section{Analysis and Discussion of Findings}

- Hypothesis 1: There is no significant difference on political values as determinants of sport participation among adolescents in Rivers State.

\begin{tabular}{|c|c|c|c|c|c|}
\hline \multicolumn{7}{|c|}{ ANOVA } \\
\hline & $\begin{array}{c}\text { Sum of } \\
\text { Squares }\end{array}$ & Df & Mean Square & F & Sig. \\
\hline Between Groups & .963 & 2 & .482 & 1.498 & .224 \\
\hline Within Groups & 320.655 & 997 & .322 & & \\
\hline Total & 321.619 & 999 & & & \\
\hline
\end{tabular}

Table 1: A Summary of ANOVA Analysis on Mean Scores of Political Values among Adolescents in Rivers State

The results in table 1 showed that the calculated F-value for the groups is 1.498 at degrees of freedom 2 and 999 and probability level 0.224 which is greater than the chosen probability level of 0.05 (F2, 999=1.498, p>0.05). Hypothesis one was accepted as a determinant. This means that no significant difference exists on political values as determinants of sport participation among adolescents in Rivers State. That is, political values are determinants of sport participation among adolescents in Rivers State.

This finding is in line with that of (Adesanya, 2001), which revealed that sport is a pervasive human activity such that ignoring it is to overlook one of the most important aspects of contemporary Nigerian society. It is a social phenomenon, which extends into education, politics, economy, art, the mass media and even international diplomatic relations. Nowadays, involvement in sport, either directly as a participant or indirectly as a spectator, is almost considered a public duty by many people all over the world. Sport is very visible in the politics of many nations; politicians realize the pervasiveness of sport and make every effort to use it for political gains. Presidents and Heads of States are well aware of the political potential of big-time sports, and this is why they never miss any opportunity to publicly associate themselves with sports. The linking of politics to sport extends beyond the local, state and national levels into international affairs. Politicians from local to national levels capitalize as much as possible on sports for self-political promotion.

Today, most countries of the world use sport as an instrument of international policy. Indeed, as far back as the early 1960s, sport was used as a visible example of the success of ideological political system. As stated by Morton (2013), 'the Soviets have made serious business out of sport competition. They have forged a direct propaganda link between sport triumph on one hand and the validity of a social system on the other. Adesanya (2001), opined that today, sport in the contemporary society has become a persuasive social phenomenon with ramifications for education, politics, economics, arts, defence, happiness and development.

Sports have assumed a fundamental dimension in the global politics of this century, and even as a potential tool for nation building as we are in the new millennium. With the activities of the United Nations Organization (U.N.O), together with its various agencies, and other fostering agencies, emphasis has now been shifted from wars, which dominated the $20^{\text {th }}$ and pre-20 $0^{\text {th }}$ century eras to sports. Sports now serve as the measure of strength among nations of the world. Sport has assumed a global dimension with well-defined and coordinated programmes. Sports have moved from just level of enjoyment, recreation and entertainment alone to being an instrument of nationalism and politics (Andah, 2006).

This finding is also in line with the observation of Mshelia (2001), who noted that Activists have always seen sport as a tool of propaganda. In the past, many African nations have suffered politically, socially and economically in the hands of their Colonial Masters. In fact, the presence of some countries was not felt in any way in Africa itself. The Olympics could not extend its arms to all Africa-countries. It was held in Congo Brazzaville, after 40 years of tireless struggles, dashed hopes and disappointments, politically created by the British and French governments, the two greatest colonial powers on the African continent.

Also in line with this finding, Mgbor (2004) opined that achievement in sport is regarded not only as an indicator of the potentialities of that nation, but also as a reflection of the superior social and political system of government. This view of his, can be hardly be faulted as the efforts of national supremacy in sports for image making by Cuba, Eastern European countries and the defunct Soviet Union during the cold war Era (1985-1990) and by Nigeria's past military juntas appear to corroborate it. Drawing a parallel line between sport and democracy in terms of emphasis on competition on the bases of equity, fairness, mass participation and the rule of law, Bhuvanendra (2008); 0jeme (1998); and Mbaye (2010) confirmed that sport is of utility in the transmission of democratic tenets, and ultimate in facilitating the growth of democracy.

Bhuvanendra (2008) viewed sport as though, seemingly trivial and trifling, but also it is an essential component of international relations and a magnificent triviality that unifies the global community as evidenced by many global sporting events such as; the Olympic games and the World Cup Tournaments. Sports in Nigeria is more than running, jumping, throwing or going for external objects for scoring points or goals. The sporting culture has been very revealing as it is bounded up with nation's history, traditions, geography, trade, politics, religions, natural wealth and even nations' health. It has been discovered that a nation's devotion to sports is one of the most powerful denominations to the national political stability (Awosika, 2005). 
Corroborating Awosika's submission, Mshelia (2001), concluded that nationalism is propagated through sports and success in sports brings a certain amount of respectability, prestige, status and national pride. Testimony to this according to him, is the fact that a country whose men and women perform reasonably well in international sports competition is granted a huge media coverage. Mshelia further stated that athletes bring a lot of honours to their fatherland, an opportunity that some other vocations do not offer. To buttress this point, Mshelia (2001), recalls that the 1996 Atlanta Olympic superlative performance and achievement enabled Nigeria's name to be written in gold and for the first time, Nigeria' national anthem was sung at the Olympics, which no doubt placed Nigeria in the eyes of the world as an emerging giant in sports. Sports have played a part in the lives of many people all over the world and today, sports is seen not just as mere physical activities, but as a means of livelihood and a political weapon as well as unifying factors.

- Hypothesis 2: Thereis no significant difference on patriotism/national pride values as determinants of sport participation among adolescents in Rivers State.

\begin{tabular}{|c|c|c|c|c|c|}
\hline \multicolumn{7}{|c|}{ ANOVA } \\
\hline & $\begin{array}{c}\text { Sum of } \\
\text { Squares }\end{array}$ & Df & Mean Square & F & Sig. \\
\hline Between Groups & .138 & 2 & .069 & .233 & .792 \\
\hline Within Groups & 294.270 & 997 & .295 & & \\
\hline Total & 294.408 & 999 & & & \\
\hline
\end{tabular}

Table 2: A Summary of ANOVA Analysis on Mean Scores of Patriotism/National Pride Values as Determinants of Sport Participation among Adolescents In Rivers State

The results in table 2 showed that the calculated F-value for the groups is 0.233 at degrees of freedom 2 and 999 and probability level 0.792 which is greater than the chosen probability level of $0.05(F 2,999=0.233, p>0.05)$. Hypothesis two was accepted. This implies that there is no significant difference on patriotism/national pride values as determinants of sport participation among adolescents in Rivers State. That is patriotism/national pride values are determinants of sport participation among adolescents in Rivers State.

This finding supports that of Awosika (2005), which found out that sport has been found to be an instrument of patriotism. Individuals, especially in a multi-national country like Nigeria could be easily integrated using sport as cohesive agent. This way, the individuals in a group can identify with their countries and government policies. It has been asserted by different scholars (Van Dalen \& Bennett, 2001; Voltmer \& Esslinger 2002; \& Andah, 2006), that sports today have assumed a global dimension with well-coordinated programmes. It has moved from the level of enjoyment, recreation and entertainment to the level of being an instrument of nationalism and politics. It is a generic term, which comprises of all arms of activities, which requires competition between two or more people.

Igbanugo (1986) stated that with perhaps the exception of politics, sport is the most competitive field of all human endeavours. Sports happily have come to be recognized as one of the most active ways of building up and mounting of character and personality of individuals. It also helps in promoting unity and solidarity among and within a community or society. Therefore, all concerned in character, moral and spiritual training of individuals must be involved in sports.

In virtually all areas of human endeavour, patriotism and national pride are key factors in the attainment or actualization of set goals. One major area of human activity where patriotism and national pride had, and still propel man to excellence is sports. Given the increasingly significant role of sports in modern society, sportsmen and women are more than ever before, seen as a mirror of their respective societies and establishments. Sport in its well-developed form is an integral part of the total make up of the society. Nations and governments of nations recognize sport as a tool for national mobilization, cultural orientation, national integration and unity, youth development and socialization, national pride and prestige, acculturation weapon of national expansion and imperialism (Ikhioya 1996). Ebhojiaye (1992) asserted that when a country defeats another in a sporting engagement, it connotes a healthier nation, fit and even more powerful than the other. By the same extension, the country's image is further boosted and reverend among others. Most small nations of the world have today been able to make their names known globally through sports,such nations as; Chile, Sweden, Finland, Spain, just to mention a few.

Nationalism is propagated through sport and success in sport brings certain amount of respectability, prestige, status, and national pride. Testimony to this is the fact that a country whose sportsmen and women perform reasonably well in international sport competitions is granted a huge media coverage. Athletes bring a lot of honour to their fatherland, an opportunity that some vocations do not offer. The 1996 Atlanta Olympics achievement enabled Nigeria's name to be written in Gold, and for the first time Nigeria's national anthem was sung at the Olympics, which no doubt placed Nigeria in the eyes of the international world as an emerging sports giant (Mshelia, 2001).

Awosika (2005) indicated that sports today is more than running, jumping and throwing or going after objects for scoring a goal or point. He pointed out that sporting culture has been very revealing, as it is bounded up with the nation's history, tradition, geography, trade, politics, religion and even nation's wealth. It has been discovered that a nation's devotion to sport is one of the most powerful denominators to top national political stability. Awosika (2005) observed that sport has always been a ready tool in the arsenal of government for mass mobilization of the citizenry-youths, adults and senior citizens alike towards national goals that include national supremacy and prestige, patriotism and support for the government. According to Scanlan and Passer (2009), sport participation is a national phenomenon, prestige is attached to sport success at school, state, national and international levels. 
Odejide (1992) asserted that, sports bring patriotism among youths, for instance, athletes tend to develop a consciousness of belonging to their state or nation, through various sporting events, both at home and abroad. Onah (1995), also discussing the importance of sport stated that world over, sports have not only been recognized, but also assigned a premier position as one of the greatest instruments of promoting global understanding and of fostering peace and unity among nations of the world. While Awosika (2000), opined that, sport has become a globally and it has also become an essential ingredient towards nation's building.

\section{Summary}

The study investigated the expressions of political and patriotism/national pride values as determinants of sport participation among adolescents in Rivers State. Consequently, the descriptive survey research design was adopted for the study. The participants consisted of nine hundred and sixty (960) secondary school adolescents, drawn from all the three Senatorial Districts of Rivers State as follows; Rivers West: (320); Rivers East: (320) and Rivers South East: (320). The participants were drawn using the convenient/accidental sampling technique. The research instrument for this study was the structured questionnaire, with a correlation co-efficient value of 0.91 . The inferential statistics of linear regression was used to test the hypotheses at 0.05 Alpha levels. The findings of the study revealed that political and patriotism/national pride values were determinants of sport participation among adolescents in Rivers State.

\section{Conclusion}

Based on the results of the findings of the researchers, it was therefore concluded that:

- Political values were determinants of sport participation among adolescents in Rivers State.

- Patriotism/national pride values were determinants of sport participation among adolescents in Rivers State.

\section{Recommendations}

The study therefore, recommended that adolescents should be more encouraged to participate in sports. Sports programmes should be frequently sponsored as this will not only provide opportunities for adolescents to participate in sports but will also help in advertising corporate businesses, government programmes and policies, as well as help in keeping the adolescents busy and as such reduce the rate of crimes, juvenile delinquencies and also enable the adolescents to make a wise use of their free time through their involvement in the sponsored wholesome and worthwhile sports programmes.

\section{Recommendations}

Consequent upon the findings of this research, the researchers hereby make the following recommendations;

- Enlightenment programmes on the values inherent from sports participation should be organized for the adolescents periodically. Through this, many adolescents who do not know the values of sports participation will be informed and consequently get involved in sports participation.

- Adolescents should be encouraged to participate in sports by providing assistance in form of money, equipment among others to them, as that will sustain their interest and facilitate their participation in sports.

\section{References}

i. Adesanya, O.A. (2001) Improvisations as a major solution to the problem of lack of physical education and sports equipment in schools. Lagos; EP Floridec.

ii. Adesanya, O.A. (2002). Some basic consideration for Nigerian University in provision and management of sports facilities. Journal of Nigeria Academy of Sports Administration I (1) 19-25.

iii. Andah, B.W. (2006). Developing sports in modern Nigeria. An overview of problems and prospects. In C.0. Udoh, A.S. Sohi and J.A Ajala (Eds) Organization of sports in Nigeria University. Proceedings of Guinness NUGA '86 Sports Clinic. Ibadan; University.

iv. Awosika, B.Y. (2000) National sports festival. 21st century and sports development in Nigeria. Abuja: Federal Ministry of Sports and Social Development. 1. 55 - 63.

v. Awosika, B. Y. (2005) Organization and administration of intramural sports. Ibadan. External studies programmes series. University of Port Harcourt; Department of Adult Education.

vi. Bhuvanendra, T.A. (2008). Human rights in the realm of sport. Olympic Review, 26 (24) 15-25.

vii. Butler, C.A (1989). School administration. St. Louis Missouri: C, V Mosby.

viii. Ebhojiaye, J.C. (1992) A handbook on physical education, sport and recreation. Lagos: S. Asekome.

ix. Grimes, A.R., (2009) A socio-economic model of national Olympic performance. In A.G. Ingham \& E.F. Bloom. Career patterns and career contingencies in sports. Proceedings of 1st Regional Symposium, International Committee for Sports Psychology. Canada; University of Vancouver.

x. Igbanugo, V.C. (1996). Physiological determinants of attitude performance. In Amusa, L.0. (Ed). The role of sports science and medicine in a developing nation. Nigeria Association of sports science and medicine. 67-58.

xi. Ikhioya, O. S. A. (1996) Understanding the problems of a vital personnel (Coach) as factor in sports growth and development. Journal of National Institute for Sport1, (1): 14 - 15.

xii. Mbaye, K. (2010), An introduction to the teaching of physical education. Birmingham; Flush.

xiii. Mgbor, M.O. (2004). Physical education in Nigerian schools. Past, present and the future. JONAPHER. S.D. 2 (1) 816 
xiv. Morton, A. (2013). Effects of incentives motivation on sports performance of amateur athletes. American Association of Sports Writers Journal. 1 (3) 99-115.

xv. Msheila, R. (2001). A sociology of education. London; Cassel Education.

xvi. National Population Commission (NPC) (2006). Report. Federal Republic of Nigeria.

xvii. NigeriaGallery(2015).RiversStateGeneralInformation.http://www.nigeriagalleria.com/Nigeria/States_Nigeria/Riv ers/Rivers_State.html.Retrieved 16 th December 2016

xviii. Odejide, M. (1992). Sports as an essential ingredient to national development. Journal of Nigerian Academy of Sports Administration, 1. 1.34-40.

xix. Ojeme, E.O. (1998). Physical education for junior secondary schools. Benin: Osahon.

xx. Onah, J.O. (1995). Goodwill message to WAUG. The mascot for 9th WAUG UNIBEN'95. 20.

xxi. Onah, M. (1995). Sport, cultural and socialization. In W. Anderze; (Ed) Introductional Review of Sport Sociology War - Saw. 417.

xxii. Scanlan, B. \& Passer, G. (2009). The theoretical notion of reciprocity and childhood socialization into sport. In A. O. Dimleavy, A. W. Miracle \& C. R. Rees (Eds). Studies in Sociology of Sport. Forthworth: Texas Christian University.

xxiii. Van Dalen, B. \& Bennet, T. (2001). An analysis of adolescents sports behaviour. Dubuque; Platinum. 